Goldschmidt 2021 Abstract

https://doi.org/10.7185/gold2021.7236

\section{SOME FEATURES OF THE GEOLOGICAL STRUCTURE AND ORE MINERALIZATION OF THE ANOROGENIC GOLD DEPOSITS IN THE WEST OF ALDAN SHIELD (SAKHA-YAKUTIA, RUSSIA)}

TAMARA TRUMM ${ }^{1}$, PLATON TISHIN ${ }^{2}$, KIRILL SOKHOREV ${ }^{1}$ AND ALEXEY GLADKOV ${ }^{1}$

${ }^{1}$ Tomsk state university

${ }^{2}$ Tomsk State University

Presenting Author: blind5518@gmail.com

The object of study is located within the Tokko-Khanin greenstone belt (the Aldan Shield) on south-western from the Ugui graben. Ore occurrence is timed the basement rocks are plagiogneisses and amphibolites of the Olekminsky metamorphic formation, of Paleoarchean age. Among the magmatic formations of the territory, Archean granites-gneisses and granites of the Charodokan formation, Neoproterozoic dikes of dolerites of the Tor formation, as well as Mesozoic sills and dikes are distinguished alkaline syenites of the Aldan formation.

Ore bodies are mineralized zones, zones of continuous metasomatites, composed of $\mathrm{K}$-feldspar-carbonate mineral association, which includes microcline, orthoclase, dolomite, ankerite, siderite-breinerite, fluorite, quartz and barite. In addition, local zones of carbonation of rocks with the formation of carbonate veins of different composition in the host rocks are recorded. metasomatites confined to the zones of large discontinuous faults, as well as to the zones of fracturing.

Figure 1. Inclusions of hessite (a) and native gold (b) in pyrite crystals.

The ore mineralization recorded in K-feldspar-carbonate metasomatites is represented by sphalerite, galenite, arsenopyrite, several generations of pyrite, including arsenic pyrite, native gold and silver phases and hessite, stutzite, fischesseritenaumanite, etc. Native gold is present in the form of teardropshaped inclusions in pyrite, or in the form of dispersed precipitates up to $10 \mu \mathrm{m}$ in size in the K-feldspar-carbonate matrix.

Mineral geothermometers found that the formation of productive mineral associations of the deposit occurred against the background of a decrease in temperatures: from 350 to $200^{\circ} \mathrm{C}$ for gold-polymetallic and $200-105^{\circ} \mathrm{C}$ for gold-telluride associations.

Thus, according to the results of the study, it is concluded that the ore occurrence is a stockwork epithermal anorogenic deposit. It is comparable to the deposits of the unconformity-type. The ores correspond to the gold-telluride formation, and their formation is associated with the Mesozoic plume activity probably.

Funding: The study was funded by RFBR according to the research project № 20-35-90036; was also been supported by Russian Mega-Grant № 14.Y26.31.0012; was also carried out at the expense of the State Task of the Ministry of Science and
Higher Education of the Russian Federation (project No. 07212020-0041).

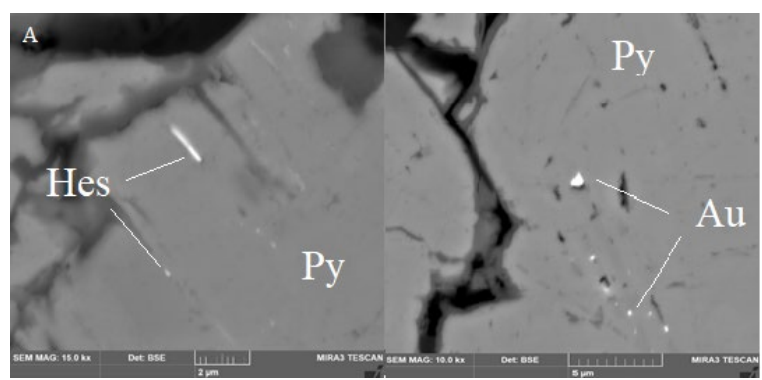

